Article

\title{
Improvement of Corrosion Resistance for Gray Cast Iron in Palm Biodiesel Application Using Thermoreactive Diffusion Niobium Carbide $(\mathrm{NbC})$ Coating
}

\author{
Ariel Amaya ${ }^{1,2}$, Oscar Piamba ${ }^{1, *}$ and Jhon Olaya ${ }^{1}$ \\ 1 Department of Mechanical and Mechatronics Engineering, Universidad Nacional de Colombia, \\ Bogotá 111321, Colombia; aaamayaa@ecci.edu.co (A.A); jjolayaf@unal.edu.co (J.O.) \\ 2 Faculty of Engineering, Coordination of Mechanical Engineering, Universidad ECCI, \\ Bogotá 111311, Colombia \\ * $\quad$ Correspondence: oepiambat@unal.edu.co; Tel.: +57-1-316-5000
}

Received: 8 May 2018; Accepted: 2 June 2018; Published: 7 June 2018

\begin{abstract}
Biodiesel is a renewable fuel consisting of alkyl esters, which show a higher corrosive behavior when compared with a diesel fuel. The corrosive processes by biodiesel affects the processing infrastructure of this biofuel and mechanical parts of automotives. Valves, engine blocks, and cylinder liners are gray cast iron components affected by biodiesel corrosion. The corrosion resistance of niobium carbide $(\mathrm{NbC})$ coatings deposited using thermoreactive diffusion (TRD) on gray cast iron in continuous contact with diesel fuel and palm biodiesel was studied. Both coated and uncoated samples were subjected to immersion tests, cyclic oxidation at $473 \mathrm{~K}$, and an electrochemical impedance spectroscopy (EIS) test. The coatings were characterized by means of scanning electron microscopy (SEM) and X-ray diffraction (XRD). Both the rate of corrosion by immersion and the resistance to polarization via EIS showed the favorable behavior of niobium carbide coatings against the corrosion of palm biodiesel. The corrosion rate on samples coated with niobium carbide was three times lower than that of the gray casting samples. These results allow the conclusion that niobium carbide coatings could be a viable alternative to lessening the corrosive effects of palm biodiesel in the applications where gray cast iron is used in continuous contact with biofuel.
\end{abstract}

Keywords: biodiesel corrosion; gray cast iron; $\mathrm{NbC}$ coating; thermoreactive diffusion TRD

\section{Introduction}

Biodiesel is a renewable fuel that is defined as a mixture of alkyl esters with fatty acids derived mainly from vegetable oils or animal fats $[1,2]$. This fuel has become important worldwide as it is technically competitive, biodegradable, and environmentally clean when compared to fossil diesel $[3,4]$. One of the most-used raw materials is palm oil because it has high agricultural yields in tropical regions. [5]. However, several studies have found that biodiesel tends to be more corrosive than fossil diesel for materials that are in contact with biofuel throughout their life cycle [2,6]. It has been demonstrated that the corrosive effect of biodiesel is a feature of the raw material used and is related to the saturation percentage of the esters, which is higher for polyunsaturated esters such as linoleate (18:02) and linolenate (18:03) [6-8]. Unsaturated esters tend to be reactive, exhibiting characteristics of autooxidation, photo-oxidation, and high hygroscopicity that promote the corrosive processes of the biofuel [7].

The corrosion behavior of biodiesel produced with different raw materials has been evaluated including canola, palm, soy, sunflower, and other oils. The evaluation technique commonly used is 
static immersion, demonstrating the greater corrosive rate of biodiesel versus diesel. Kaul et al. [1] observed that biodiesel from Jatropha curcas and Salvadora produced severe corrosion on foundry iron and aluminum. It was found that biodiesel caused deterioration to the mechanical parts, and its effects accelerated considerably when the fuel oxidized or when it absorbed humidity from the environment [9]. Maru et al. [10] observed in long-term immersion tests at room temperature that biodiesel derived from soybean and sunflower oils caused significant modifications to the surface finish of carbon steel. Fazal et al. [11] found a direct relationship between an increase in temperature and the corrosion rate in low-carbon steels exposed to palm biodiesel as well as the degradation of fuel properties. Fazal et al. [2] suggested that materials such as bronze, copper, steel, and aluminum were metals that reacted with the fuel and tended to corrode in contact with palm biodiesel to form sediments that increased the ionic conductivity of the fuel. Geller et al. [12] evaluated the corrosion resistances of 316 stainless steel, cast iron, copper, and brass with various percentages of biodiesel from animal fat and diesel, resulting in an increase in corrosion rate with the increase in the biodiesel content in the mixture.

Gray iron is a commonly used material in the petrochemical process, automotive, and energy transformation industry parts. This material can be found in pumps, valves, engine blocks, and cylinder liners, where they can be at high temperature, corrosion, and wear conditions. Fazal et al. [13] performed immersion tests on palm biodiesel at room temperature $(288 \mathrm{~K})$ for $1200 \mathrm{~h}$ on gray iron. They found a corrosion rate of $0.079 \mathrm{mpy}$, identified by iron oxide $\left(\mathrm{FeO}\right.$ and $\left.\mathrm{Fe}_{2} \mathrm{O}_{3}\right)$ on the surface. These results were confirmed through immersion tests in palm biodiesel with different inhibitors at ambient temperature where the formations of $\mathrm{FeCO}_{3}, \mathrm{Fe}_{2} \mathrm{O}_{3}, \mathrm{Fe}(\mathrm{OH})_{2}$, and $\mathrm{Fe}_{2}(\mathrm{OH})_{2} \mathrm{CO}_{3}$ were evidenced due to the presence of water, biodiesel, and a fraction of unsaturated esters of biodiesel [2]. M'Peko et al. [14] proposed the application of electrochemical techniques in order to study the anticorrosive properties of biofuels. They evaluated biodiesel from four different raw materials (sunflower, soybean, canola, and maize) on stainless steel using the method of electrochemical impedance spectroscopy (EIS). It was observed that the polarization resistance varied with the raw material between 4.8 and $16.3 \mathrm{G} \Omega$, obtaining the best behavior for sunflower biodiesel. Furthermore, they established a viable methodology for performing electrochemical analysis in highly resistive media. Additionally, Aquino [15] evaluated soybean biodiesel via EIS using support electrolytes on different metallic materials. It was found that the polarization resistance for carbon steel was $11.0 \mathrm{G} \Omega$, stainless steel $12.7 \mathrm{G} \Omega$, aluminum $2.1 \mathrm{G} \Omega$, and copper $1.68 \mathrm{G} \Omega$, confirming that electrochemical techniques are an efficient method for determining the corrosive effects produced by biofuels. Amaya et al. [16] carried out immersion tests with diesel and palm biodiesel on gray iron and found that the gray iron underwent a process of decarburization and corrosion through pitting when it was in prolonged contact with palm biodiesel.

The production of hard coatings via the thermoreactive diffusion (TRD) technique presents commercial advantages over the PVD and CVD processes as the TRD does not require sophisticated vacuum equipment, has a low processing cost, and requires economical supplies $[17,18]$. In the literature, there has been important research about TRD for the production of niobium carbides [19], vanadium [18], and chromium [20], among others. In general, niobium carbides have been deposited on AISI, H13, M2, and D2 steels, with microstructure characterization, wear resistance, and growth kinetics studies [21-25]. Amaya et al. [26] reported the production of hard vanadium carbide coatings on gray iron casting via the TRD technique in bath salts, with a process temperature of $1223 \mathrm{~K}$ and a deposition time of $4 \mathrm{~h}$, achieving layer thicknesses greater than $7 \mu \mathrm{m}$.

Corrosion effects of biodiesel on gray cast iron reduces the safety, lifetime, and functionality of mechanical parts. The niobium carbide deposited by the TRD process on gray iron could enhance the corrosion resistance of the substrate. This research paper explains the application of a niobium carbide coating to improve the corrosion resistance of gray cast iron. $\mathrm{NbC}$ coatings will be produced and characterized. Corrosion tests on gray cast iron and $\mathrm{NbC}$ coatings samples will be developed and 
the results will be compared to define if the proposed coat would be useful to protect the substrate from corrosion by biodiesel.

\section{Materials and Methods}

The fuels evaluated were diesel derived from commercial petroleum with a sulfur content of less than $500 \mathrm{ppm}$, and biodiesel obtained from palm oil through methyl transesterification with a composition of mainly $42.5 \%$ methyl ester palmitate, $40.7 \%$ methyl ester oleate, and $10 \%$ methyl ester linoleate. The total fraction of the unsaturated esters was $51.7 \%$. Table 1 summarizes the analysis reported by the producer of palm oil biodiesel, according to specifications and test methods according to ASTM D6751-15c [27].

Table 1. Analysis report of palm biodiesel.

\begin{tabular}{cccc}
\hline Tests & Units & Range & Measured Values \\
\hline Density at $15{ }^{\circ} \mathrm{C}$ & $\mathrm{kg} / \mathrm{m}^{3}$ & $860-900$ & 879 \\
Viscosity at $40^{\circ} \mathrm{C}$ & $\mathrm{mm}^{2} / \mathrm{s}$ & $1.9-6.0$ & 4.46 \\
Flashpoint & ${ }^{\circ} \mathrm{C}$ & Min. 120 & 271 \\
Cetane number & - & Min. 47 & 74.1 \\
Total ester content & $\%(\mathrm{~m} / \mathrm{m})$ & Min. 96.5 & 98.8 \\
Moisture & $\mathrm{mg} / \mathrm{kg}$ & Max. 500 & 497 \\
Methanol content & $\%(\mathrm{~m} / \mathrm{m})$ & Max. 0.20 & 0.18 \\
Total glycerol & $\%(\mathrm{~m} / \mathrm{m})$ & Max. 0.25 & 0.22 \\
\hline
\end{tabular}

The specimens were obtained from an unused cylinder liner of a diesel engine. This material was a G3500 grey iron $(93.1 \% \mathrm{Fe}, 3.45 \% \mathrm{C}$, and $1.66 \% \mathrm{Si})$ with a density of $7.21 \mathrm{~g} / \mathrm{cm}^{3}$ and pearlite structure with the graphite distributed uniformly. Based on the ASTM A48M standard [28], it was determined that the microstructure of the cast iron was type 30 due to presence of pearlite in the matrix and lamellar graphite type size 5 [8].

Samples of $4 \mathrm{~cm}^{2}$ and $0.5 \mathrm{~cm}$ thick square substrates were obtained by refrigerated cutting. The samples were polished with abrasive papers of silicon carbide (grade 400-1500), achieving a surface free of scratches. Half of the casting samples were coated with niobium carbide in a bath of borax salts. The TRD coating process was carried out in a borax bath perfused at $1123 \mathrm{~K}$ at $81 \mathrm{wt} . \%$; subsequently, the temperature was raised to that of the process and ferro-niobium (16\%) and aluminum $(3 \%)$ were added as reducing agents. The bath was performed in stainless steel containers due to its low carbon content, thus avoiding interaction with the process. The $\mathrm{NbC}$ coating was prepared separately at $1173 \mathrm{~K}, 1223 \mathrm{~K}$, and $1273 \mathrm{~K}$, at three processing times: 2, 4, and $6 \mathrm{~h}$. The samples were withdrawn upon completion of the treatment time and were rapidly cooled in order to avoid passing through the temperature that causes substrate embrittlement. They were then immersed in boiling water for $30 \mathrm{~min}$ to remove the excess borax produced by the bath.

The coating's microstructure was studied via X-ray diffraction (XRD) using an X'Pert PRO system (Panalytical, Almelo, The Netherlands) for grazing incidence with the Bragg-Brentano configuration and monochromatized $\mathrm{CuK} \alpha$ radiation $(1.540998 \AA$ ) , working at $45 \mathrm{kV}$ and $40 \mathrm{~mA}$. The scan was conducted within the angular range $2 \theta$ from $25^{\circ}$ to $100^{\circ}$ with a step of $0.02^{\circ}$ and a monochromatic $\mathrm{CuKa}$ radiation of $1.594 \AA$. The surface morphology of the coatings deposited on the gray iron substrates, and the corrosion products and the transversal section were studied via scanning electron microscopy (SEM) using FEI QUANTA 200 equipment (Thermo Fisher Scientific, Waltham, MA, USA) operating in high vacuum and $30 \mathrm{KV}$. In addition, to verify the presence of the coating, Auger Electron Spectroscopy (AES) surface tests were performed with an Omicron Nanotechnology CMA 169 (Oxford Instruments, Abingdon, UK) with an evaluation range between 40 and $400 \mathrm{eV}$ at intervals of $0.5 \mathrm{eV}$. The coating thickness was measured using a 500 optical microscope (LECO Corporation, St. Joseph, MI, USA) and the images were analyzed in the IA32 Image Analysis System (LECO Corporation, St. Joseph, MO, USA), with a magnification of $2000 \times$. 
Corrosion behavior was determined using three tests: (1) an immersion test at constant temperatures of $291 \mathrm{~K}$ and $313 \mathrm{~K}$, (2) a cyclic oxidation test with heating and cooling cycles between $291 \mathrm{~K}$ and $473 \mathrm{~K}$ for a total time of $1320 \mathrm{~h}$ (55 days), and (3) electrochemical impedance spectroscopy (EIS). The immersion and cyclic oxidation were done with hermetically sealed containers completely filled with fuel, with three replicates for each test. Subsequent to the immersion test, the samples were introduced into the ultrasound equipment in a solution of hydrochloric acid and tin chloride at room temperature to remove the corrosion products. The weight loss was measured according to the procedure of ASTM G31-72 [29], and the corrosion rate was evaluated using the following equation:

$$
\text { Corrosion Rate }(\mathrm{mpy})=\frac{\mathrm{W}(\mathrm{g}) \times 3.45 \times 10^{6}}{A\left(\mathrm{~cm}^{2}\right) \times \rho\left(\mathrm{g} / \mathrm{cm}^{3}\right) \times t(\mathrm{~h})}
$$

where the corrosion rate is given in 0.001 inches per year; $W$ is the weight lost during exposure to the corrosive medium (g); $3.45 \times 10^{6}$ is the unit conversion factor; $\rho$ is the density $\left(\mathrm{g} / \mathrm{cm}^{3}\right) ; A$ is the exposed surface $\left(\mathrm{cm}^{2}\right)$; and $t$ is the exposure time (h) [29,30].

Electrochemical impedance spectroscopy tests were also performed for the samples for a period of $144 \mathrm{~h}$ at $291 \mathrm{~K}$ using a 3-electrode electrochemical cell with a silver pseudo electrode as a reference. The electrochemical cell was constructed with one working electrode of $4 \mathrm{~cm}^{2}$, located in parallel to a high-density electrolytic graphite sheet, used as an auxiliary electrode. Silver wires (Ag) with a $0.5 \mathrm{~mm}$ diameter were used as a reference electrode. The testing sample was mounted on the working electrode and exposed to the electrolyte through an orifice with a diameter of $10 \mathrm{~mm}$ providing an exposure area of $78.54 \mathrm{~mm}^{2}$. The separation between the working electrode and reference electrode was $0.5 \mathrm{~mm}$. Electrochemical measurements were performed with a Gamry-Reference 600 (Gamry Instruments, Inc., Philadelphia, PA, USA). The amplitude of the disturbing signal used was $200 \mathrm{mV}$ with a frequency range of $0.00001-100 \mathrm{kHz}$. Experiments were repeated at least three times for each material evaluated and were conducted in a Faraday cage. The experimental data were acquired with the EIS300 module and analyzed using Echem Analyst software (Gamry Instruments, Inc., Philadelphia, PA, USA).

\section{Results and Discussion}

Figure 1a,b show the etched cross-section and surface morphology of the $\mathrm{NbC}$ coating on the substrate. The carbide layer and the gray iron were clearly defined and separated by an interface without the presence of a transition zone between the coating and the substrate. The coating exhibited a compact, continuous, and homogeneous structure with constant thickness, consistent with previous studies $[13,20,21]$. The morphology of the coating was dependent on the carbon activity in the substrate [20]. Ferrous materials with high carbon content such as gray cast iron have a relative low carbon activity, which results in low nucleation density and a poor supply of carbon atoms for the formation of carbide. Several sub-micron-sized grains produced on the substrate surface in the initial stage of the TRD process were observed [20]. The coarse grains can grow from these initial grains by increasing their size and number with the increase in time to form a continuous thin layer on the gray iron surface. Then, the morphology changed with elongated grains in the direction perpendicular to the coating/substrate interface and sub-micron grains on the surface parallel to the coating/substrate interface [20]. 


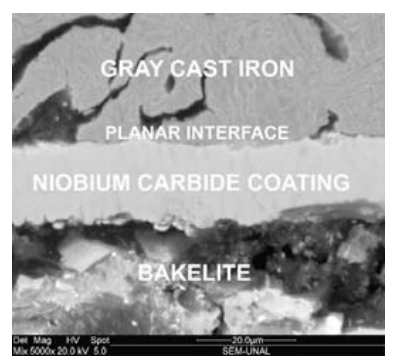

(a)

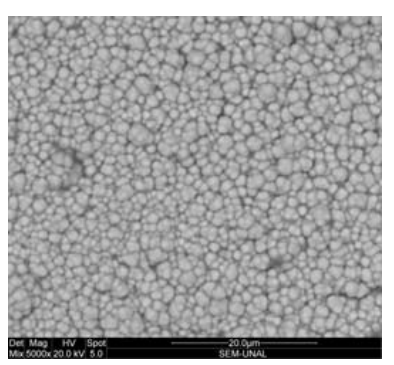

(b)

Figure 1. SEM micrograph $5000 \times$ of: (a) cross section and (b) surface of $\mathrm{NbC} 1223 \mathrm{~K}$ for $4 \mathrm{~h}$.

Niobium carbide coating thicknesses ranging from $3.47 \pm 0.27$ to $13.81 \pm 0.35 \mu \mathrm{m}$ at $1173 \mathrm{~K}$ to $1273 \mathrm{~K}$ for $2 \mathrm{~h}$ and $6 \mathrm{~h}$, respectively, were obtained. Figure 2 shows that the coating thickness increased with the duration of the treatment and the temperature, which is in agreement with classical kinetic theory $[23,31]$. Based on these results, the coating system produced with a treatment time of $4 \mathrm{~h}$ and deposition temperature of $1223 \mathrm{~K}$ was selected for the corrosion tests. This treatment allows for coatings with homogeneous surfaces to be obtained with a layer thickness of $10 \mu \mathrm{m}$, and has a low energy cost among the treatments.

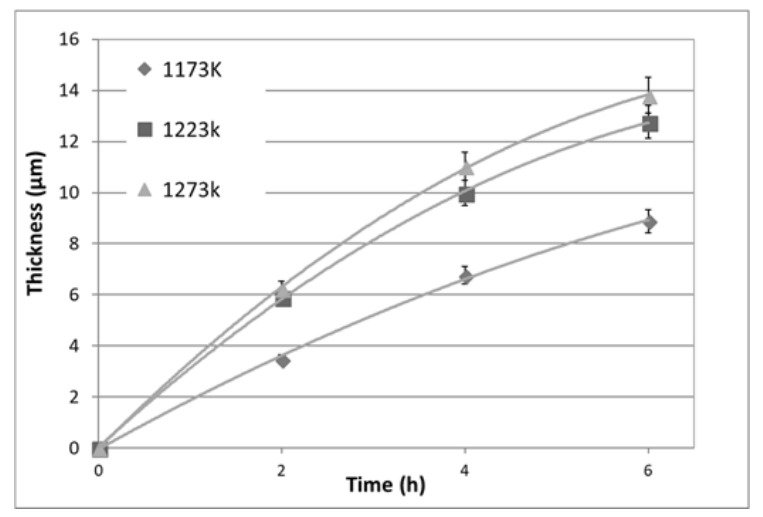

Figure 2. $\mathrm{NbC}$ coating thickness vs. time TRD at various treatment temperatures.

The results obtained from the AES testing were analyzed using the database of the National Institute of Standards and Technology (NIST). The presence of mainly niobium (167 eV) and carbon $(272 \mathrm{eV})$ was verified. The analysis of the atomic concentration showed $50.75 \%$ carbon for the KLL transition and $50.75 \%$ niobium for the MNN transition (Figure 3).

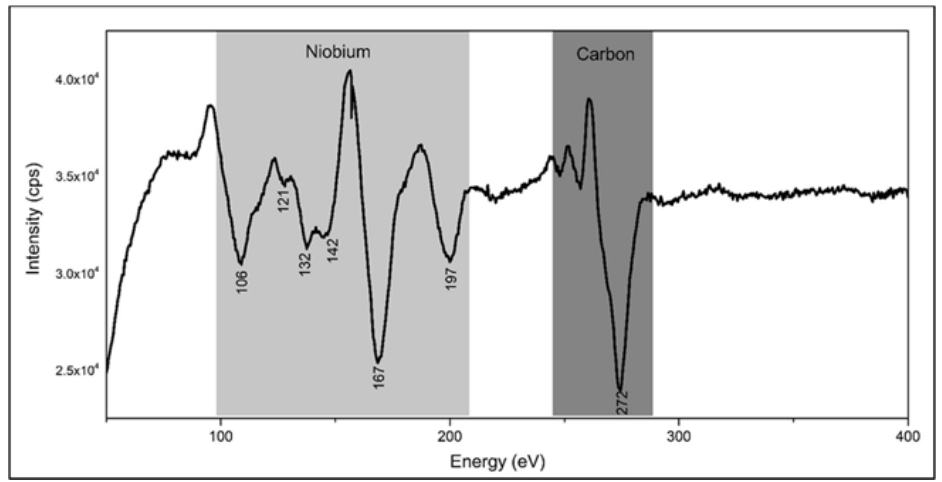

Figure 3. AES spectrum of $\mathrm{NbC} 1223 \mathrm{~K}$ for $4 \mathrm{~h}$. 
XRD analysis of the carbide layer produced on the gray cast iron at $1223 \mathrm{~K}$ for $4 \mathrm{~h}$ is shown in Figure 4. The cubic phase of NbC was confirmed according to the JCPDS 000381364 card, showing high intensity peaks with a mixed orientation of mainly crystal planes (111), (200), (220), and (311). No significant effect of the composition of the salt bath or the substrate was observed in the orientations observed. $\mathrm{NbC}$ had a cubic crystal structure similar to $\mathrm{NaCl}(\mathrm{Fm} 3 \mathrm{~m})$ and space group number 225.

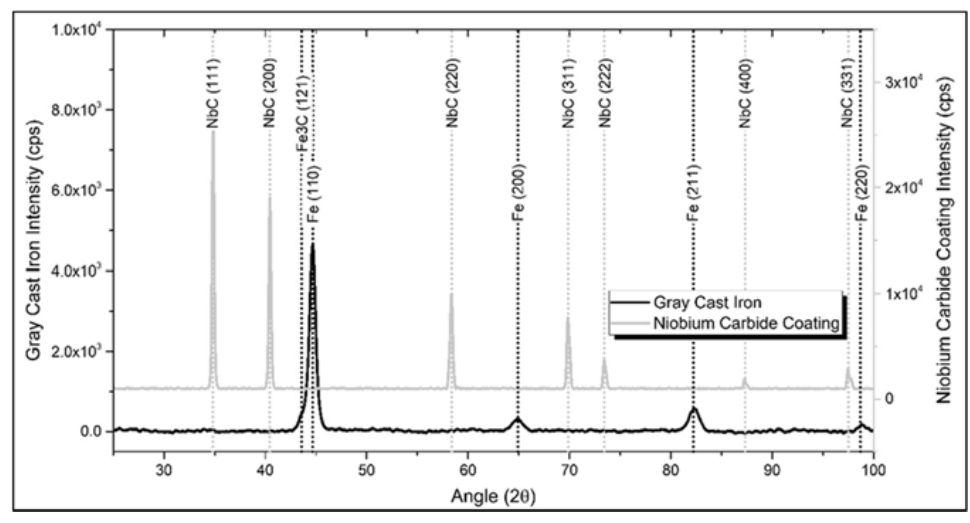

Figure 4. XRD spectrum of gray cast iron and $\mathrm{NbC}$ coating for $4 \mathrm{~h}$ at $1223 \mathrm{~K}$.

Figure 5 shows the results of the corrosion rate for the samples submerged in the diesel and biodiesel fuels. It was observed that diesel fuel caused a lower corrosion rate for each material. The niobium carbide coating led to a reduction of three times in the corrosion rate of the two fuels, considering the three temperature regimes of the test: $291 \mathrm{~K}, 313 \mathrm{~K}$, and cyclic oxidation. Furthermore, in the cyclic oxidation test, the coating submerged in biodiesel had a better performance ( $0.78 \mathrm{mpy})$ when compared to the diesel-submerged cast iron $(0.80 \mathrm{mpy})$, indicating a higher durability of the components used in this type of application than the material traditionally used. In general, it was observed that with an increase in temperature, the speed of corrosion of the samples accelerated. The corrosive effect was greater for the case of diesel in the cyclic oxidation test, which could be associated with the greater activity of the sulfur molecules; this is the main cause of corrosion by this fuel and it is absent in the case of palm biodiesel [32].

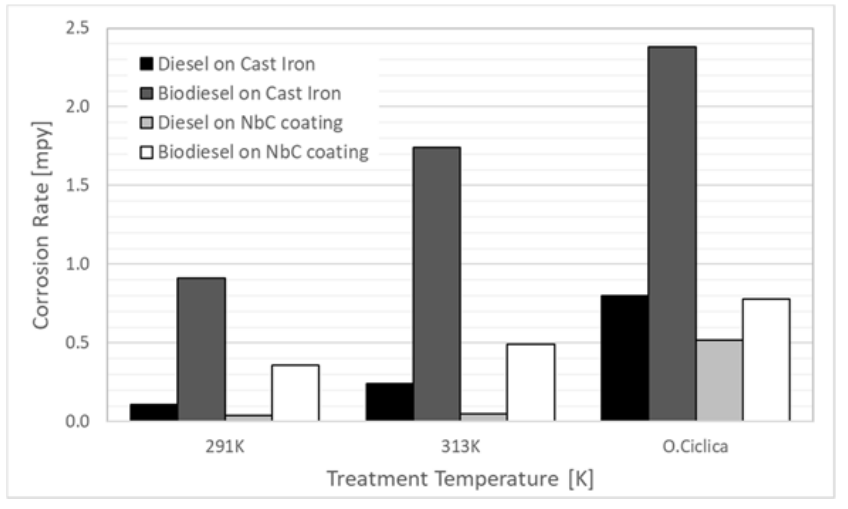

Figure 5. Corrosion rates of the gray cast iron and $\mathrm{NbC}$ coating in diesel and biodiesel.

Field Emission Gun Scanning Electron Microscope (SEM-FEG) was used to analyze the morphology of the surface after the process of corrosion by static immersion. The most representative micrographs of smelting and coating are shown in Figure 6, after an exposure of $1320 \mathrm{~h}$ and a cyclic oxidation (OC) state. The gray iron showed a partial loss of graphite through the grooves produced by a process of selective corrosion of the ferrite phase of the pearlite structure. Surface pitting was 
also observed, with sizes ranging from 20 to $100 \mu \mathrm{m}$ and smaller sizes ( $\pm 2 \mu \mathrm{m})$ distributed randomly on the surface (Figure $6 \mathrm{a}$ ). Figure $6 \mathrm{~b}$ shows the niobium carbide coating, where there was neither representative pitting on the surface nor corrosion on a large scale. Figure 7 shows the surface of the coating at a higher magnification, which allowed the identification of the intergranular oxide growth in small quantities.

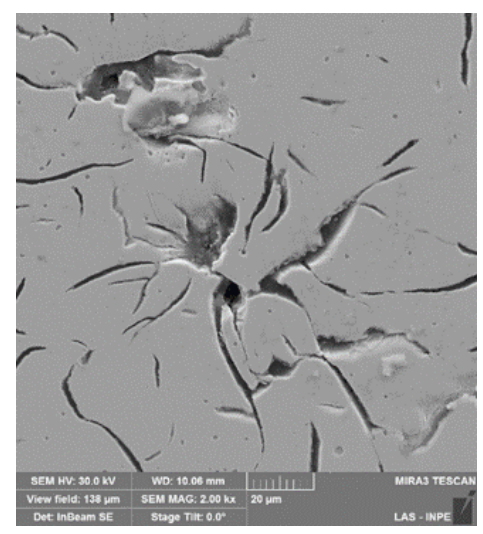

(a)

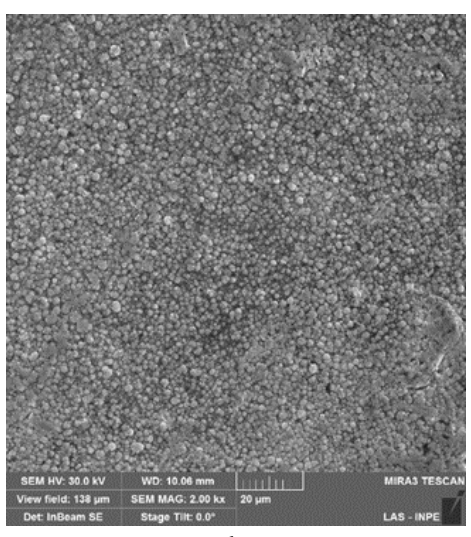

(b)

Figure 6. SEM-FEG micrograph on the surface exposed to palm biodiesel by $1320 \mathrm{~h}$. (a) Gray cast iron and (b) $\mathrm{NbC}$ coating.

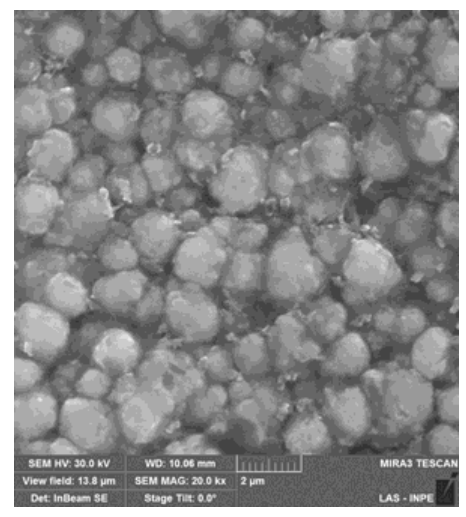

Figure 7. SEM-FEG Micrograph of $\mathrm{NbN}$ coating exposed to palm biodiesel at $1320 \mathrm{~h}$.

The X-ray patterns made by the iron smelter before and after the biodiesel corrosion process are shown in Figure 8. The analysis allowed the identification of new peaks associated with $\mathrm{Fe}_{2} \mathrm{O}_{3}$ (hematite), $\mathrm{Fe}_{3} \mathrm{O}_{4}$ (magnetite), and $\mathrm{FeO}(\mathrm{OH})$ (goethite) [3]. Figure 9 shows the X-ray pattern of the niobium carbide coating prior and after exposure to biodiesel. The presence of additional peaks related to $\mathrm{NbO}, \mathrm{NbO}_{2}$, and $\mathrm{Nb}_{2} \mathrm{O}_{5}$ was observed. The diffractograms showed that the two surfaces interacted with the biodiesel and that different species of oxides appeared, which were produced during the corrosion process [24]. 


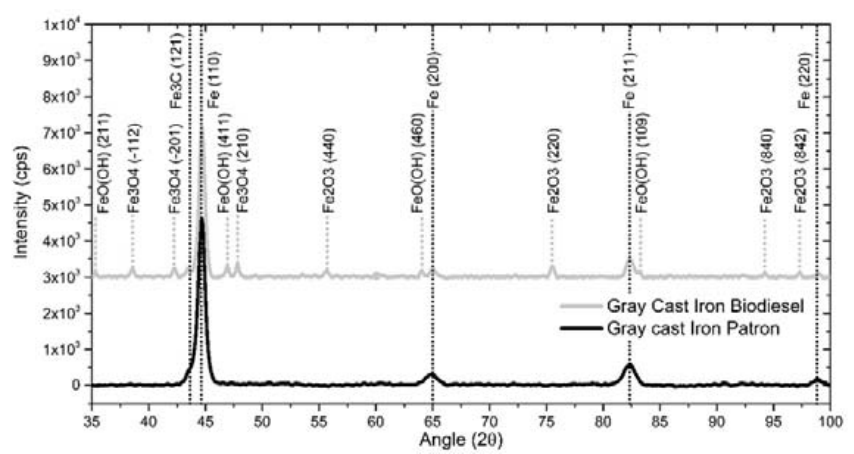

Figure 8. XRD spectrum of the gray cast iron before and after exposure to palm biodiesel at $1320 \mathrm{~h}$ in OC.

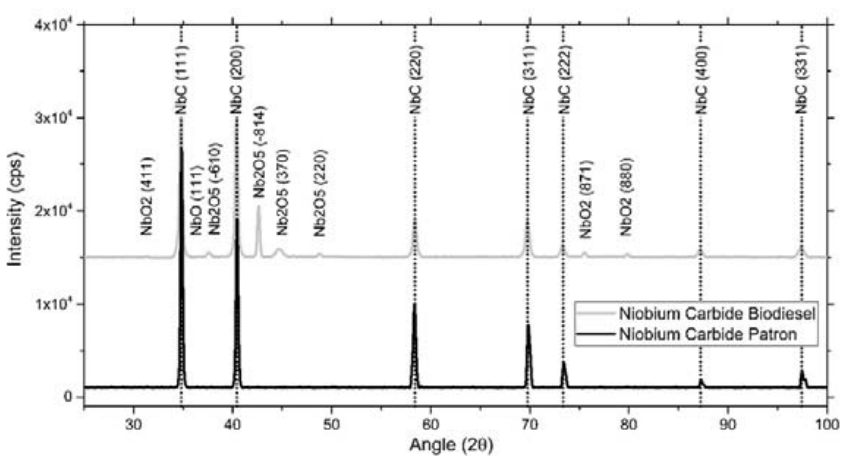

Figure 9. $\mathrm{XRD}$ spectrum of the $\mathrm{NbC}$ coating before and after exposure to palm biodiesel at $1320 \mathrm{~h}$ in OC.

Figure 10 shows the Nyquist diagrams obtained from the electrochemical impedance test performed on the niobium carbide coating submerged in biodiesel at a temperature of $291 \pm 2 \mathrm{~K}$ with immersion times of $1 \mathrm{~h}, 24 \mathrm{~h}, 48 \mathrm{~h}$, and $144 \mathrm{~h}$. It was observed that the diagram was composed of two overlapping semicircles, suggesting the presence of two constant phase elements corresponding to two electrolyte-electrode interphases. The first, at high frequencies and a larger radius, is usually associated with the resistive-capacitive behavior of the coating; and the second time constant was related to the electrolyte-substrate interface due to the pores in the coating [24,25]. The polarization resistance decreased from $1.48 \times 10^{10} \Omega$ to $8.95 \times 10^{9} \Omega$ with an increase in the immersion time. This could be explained by the corrosive solution penetrating through the coating defects to the substrate surface.

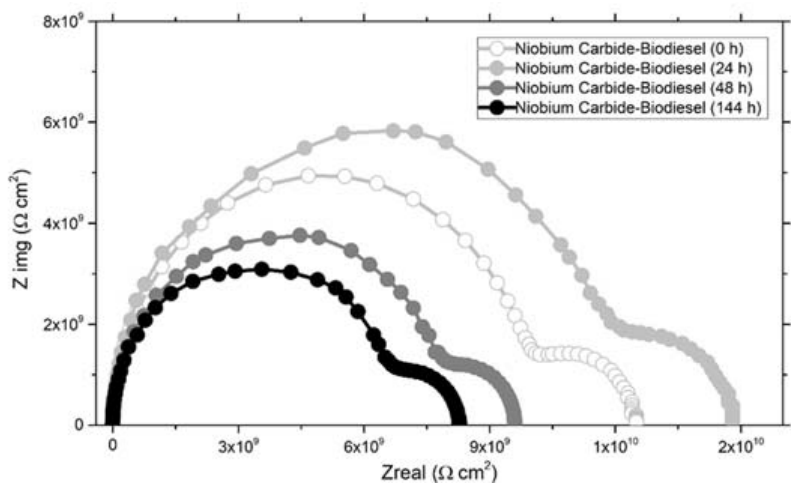

Figure 10. Nyquist diagrams obtained via EIS on the niobium carbide coating in contact with palm biodiesel at $291 \pm 2 \mathrm{~K}$ at different exposure times.

Figure 11 shows the Nyquist diagrams obtained for the niobium carbide coating when compared to the substrate in contact with diesel fuel and biodiesel for $144 \mathrm{~h}$ of exposure time. It was observed that the gray iron diagram was composed of a time constant that corresponded to the resistive-capacitive 
behavior of the substrate double layer, which agreed with the results reported by M'Peko et al. [14], while the coating was composed of two semicircles, as already mentioned. The $\mathrm{NbC}$ coating exhibited greater resistance to polarization when compared to the gray iron with respect to the two evaluated fuels. Likewise, the evaluated materials exhibited a lower corrosion resistance in the biodiesel, which showed a greater reactivity of the unsaturated methyl ester in the fuel. The results obtained via EIS were in agreement with those obtained in the immersion tests, proving their effectiveness in reducing the corrosive effects of the biofuel.

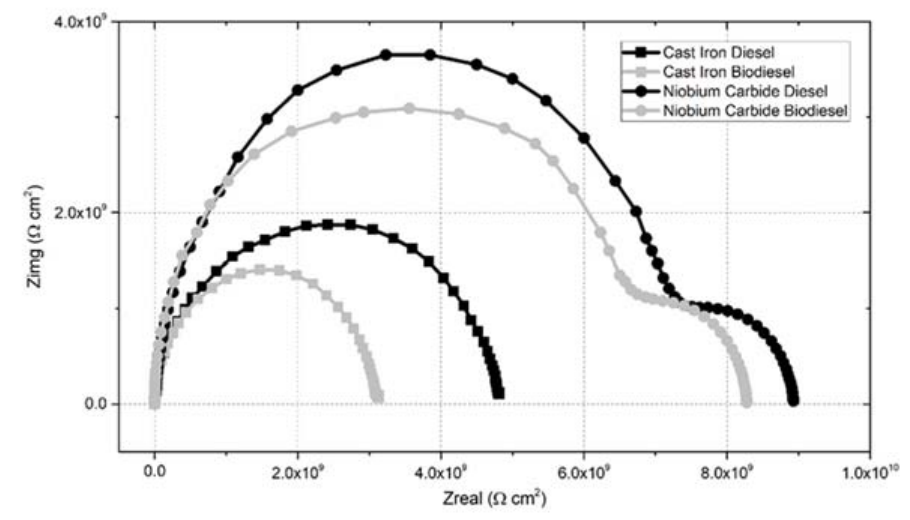

Figure 11. Nyquist diagrams obtained via EIS for smelting iron and niobium carbide coating in contact with diesel and palm biodiesel at $291 \pm 2 \mathrm{~K}$ and $144 \mathrm{~h}$.

Figure 12 shows the values of the polarization resistance for the coating and the substrate in the corrosive environments of diesel and biodiesel as a function of the immersion time. It was observed that the coated samples exhibited higher polarization resistance with respect to gray iron throughout the evaluation period, being three times higher when the test was done in biodiesel and 1.4 times in diesel. The higher corrosion rate or less polarization resistance measured in the biodiesel-gray iron system may correspond to greater reactivity and the formation of iron oxides, according to the mechanism proposed by Aquino [15]. This corrosive process occurs simultaneously with the biodiesel autooxidation processes, which degrade the fuel and produce aldehydes, carboxylic acids, alcohols, sediments, and insoluble gums [33]. The coating anticorrosive properties are associated with the ceramic structure of $\mathrm{NbC}$, with the cubic structure requiring higher energies in order to be transformed into corrosion products. The corrosion properties observed in the $\mathrm{NbC}$ coatings have been studied in previous works by Orjuela et al. [25] and Fernandez et al. [34], who evaluated corrosion behavior in saline atmospheres and obtained satisfactory results similar to those obtained in this research.

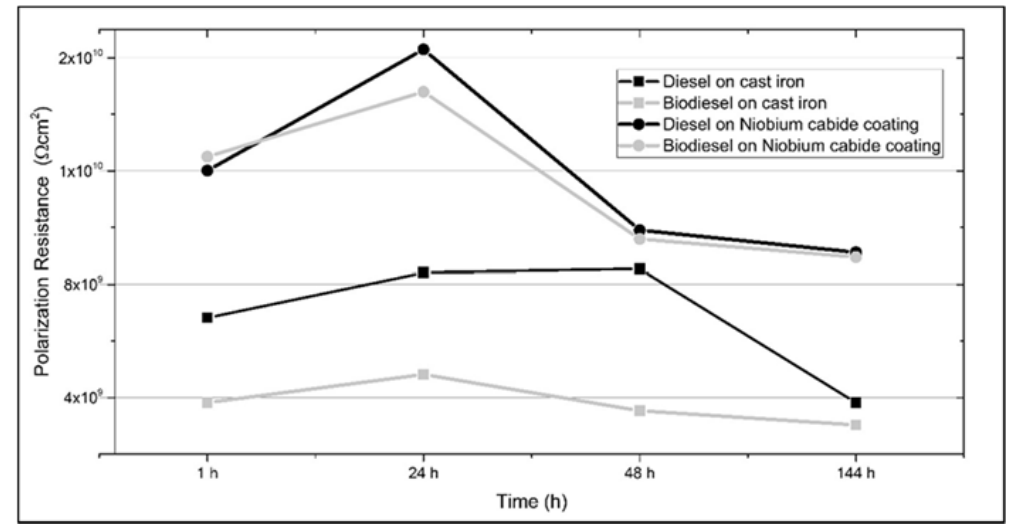

Figure 12. Polarization resistance obtained from the Nyquist diagrams via EIS on the cast iron and niobium carbide coating in contact with the diesel and palm biodiesel at $291 \pm 2 \mathrm{~K}$. 


\section{Conclusions}

The results of the corrosion tests using immersion and electrochemical impedance spectroscopy showed that niobium carbide coatings offer high anticorrosive properties for protection from degradation in environments of palm biodiesel when compared to gray iron.

From the immersion tests, it was determined that the corrosion rates in the biodiesel test was three times lower for the coated samples due to the ceramic structure. The SEM and XRD tests showed severe effects of pitting corrosion in the grey iron with the presence of $\mathrm{Fe}_{2} \mathrm{O}_{3}, \mathrm{Fe}_{3} \mathrm{O}_{4}$, and $\mathrm{FeO}(\mathrm{OH})$, while the $\mathrm{NbC}$ coatings exhibited effects of intergranular corrosion in the grain boundaries with the presence of $\mathrm{NbO}, \mathrm{NbO}_{2}$, and $\mathrm{Nb}_{2} \mathrm{O}_{5}$. These results allowed the conclusion that $\mathrm{NbC}$ coatings on gray iron act as protection against corrosion by palm biodiesel.

Author Contributions: O.P. and J.O. conceived and designed the experiments; A.A. performed the experiments; and O.P., J.O. and A.A. wrote the paper.

Funding: This research was funded by National University of Colombia, Research Division Bogotá (No. 19070 and 14230).

Conflicts of Interest: The authors declare no conflicts of interest.

\section{References}

1. Kaul, S.; Saxena, R.C.; Kumar, A.; Negi, M.S.; Bhatnagar, A.K.; Goyal, H.B.; Gupta, A.K. Corrosion behavior of biodiesel from seed oils of Indian origin on diesel engine parts. Fuel Process. Technol. 2007, 88, 303-307. [CrossRef]

2. Fazal, M.A.; Haseeb, A.S.M.A.; Masjuki, H.H. Degradation of automotive materials in palm biodiesel. Energy 2012, 40, 76-83. [CrossRef]

3. Jin, D.; Zhou, X.; Wu, P.; Jiang, L.; Ge, H. Corrosion behavior of ASTM 1045 mild steel in palm biodiesel. Renew. Energy 2015, 81, 457-463. [CrossRef]

4. Fazal, M.A.; Haseeb, A.S.M.A.; Masjuki, H.H. Biodiesel feasibility study: An evaluation of material compatibility; performance; emission and engine durability. Renew. Sustain. Energy Rev. 2010, 15, 1314-1324. [CrossRef]

5. Kalam, M.A.; Masjuki, H.H. Biodiesel from palm oil—An analysis of its properties and potential. Biomass Bioenergy 2002, 23, 471-479. [CrossRef]

6. Singh, B.; John Korstad, J.; Sharma, Y.C. A critical review on corrosion of compression ignition (CI) engine parts by biodiesel and biodiesel blends and its inhibition. Renew. Sustain. Energy Rev. 2012, 16, 3401-3408. [CrossRef]

7. Fazal, M.A.; Haseeb, A.S.M.A.; Masjuki, H.H. Comparative corrosive characteristics of petroleum diesel and palm biodiesel for automotive materials. Fuel Process. Technol. 2010, 91, 1308-1315. [CrossRef]

8. Castro, J.; Piamba, O.E.; Olaya, J.J. Pruebas de corrosión cíclica de fundiciones de hierro gris en diferentes biodiesel. Ing. Mec. Tecnol. Desarro. 2016, 5, 423-429.

9. Wang, W.; Jenkins, P.E.; Ren, Z. Heterogeneous corrosion behavior of carbon steel in water contaminated biodiesel. Corros. Sci. 2011, 53, 845-849. [CrossRef]

10. Maru, M.; Lucchese, M.; Legnani, C.; Quirino, W.; Balbo, A.; Aranha, I.; Costa, L.; Vilani, S.; Sena, L.; Damasceno, J.; et al. Biodiesel compatibility with carbon steel and HDPE parts. Fuel Process. Technol. 2009, 90, 1175-1182. [CrossRef]

11. Fazal, M.A; Haseeb, A.S.M.A.; Masjuki, H.H. Effect of temperature on the corrosion behavior of mild steel upon exposure to palm biodiesel. Energy 2011, 36, 3328-3334. [CrossRef]

12. Geller, D.P.; Adams, T.T.; Goodrum, J.W.; Pendergrass, J. Storage stability of poultry fat and diesel fuel mixtures: Specific gravity and viscosity. Fuel 2008, 87, 92-102. [CrossRef]

13. Fazal, M.A.; Haseeb, A.S.M.A.; Masjuki, H.H. Effect of different corrosion inhibitors on the corrosion of cast iron in palm biodiesel. Fuel Process. Technol. 2011, 92, 2154-2159. [CrossRef]

14. M'Peko, J.C.; Reis, D.L.S.; De Souza, J.E.; Caires, A.R.L. Evaluation of the dielectric properties of biodiesel fuels produced from different vegetable oil feedstocks through electrochemical impedance spectroscopy. Int. J. Hydrog. Energy 2013, 38, 9355-9359. [CrossRef] 
15. Aquino, I.P. Avaliação da Corrosividade do Biodiesel por Técnicas Gravimétricas e Electroquímicas. Ph.D. Thesis, Universidade de São Paulo, São Paulo, Brasil, 2012.

16. Amaya, A.A.; Piamba, O.E.; Olaya, J.J. Study of the corrosive effects of diesel and biodiesel on gray cast iron. Rev. Latinam. Metal. Mater. 2014, 34, 289-295.

17. Arai, T.; Harper, S. Thermoreactive Deposition/Diffusion Process for Surface Hardening of Steels. In ASM Handbook Volume 4A: Steel Heat Treating Fundamentals and Processes; ASM International: Materials Park, OH, USA, 2017; Volume 4, pp. 725-740. ISBN 978-1-62708-026-2.

18. Arai, T.; Fujita, H.; Sugimoto, Y.; Ohta, Y. Vanadium Carbonitride Coating by Immersing into Low Temperature Salt Bath. In Heat Treatment and Surface Engineering, 1st ed.; Krauss, G., Ed.; ASM International: Materials Park, OH, USA, 1988; pp. 49-53. ISBN 0871703343.

19. Oliveira, C.K.N.; Riofano, R.M.M.; Casteletti, L.C. Micro-abrasive wear test of niobium carbide layers produced on AISI H13 and M2 steels. Surf. Coat. Technol. 2006, 200, 5140-5144. [CrossRef]

20. Su, Y.L.; Yao, S.H. On the performance and application of CrN coating. Wear 1997, 205, 112-119. [CrossRef]

21. Oliveira, C.K.N.; Benassi, C.L.; Casteletti, L.C. Evaluation of hard coatings obtained on AISI D2 steel by thermo-reactive deposition treatment. Surf. Coat. Technol. 2006, 201, 1880-1885. [CrossRef]

22. Sen, S.; Sen, U. Sliding wear behavior of niobium carbide coated AISI 1040 steel. Wear 2008, 264, $219-225$. [CrossRef]

23. Sen, U. Kinetics of niobium carbide coating produced on AISI 1040 steel by thermo-reactive deposition technique. Mater. Chem. Phys. 2004, 86, 189-194. [CrossRef]

24. Castillejo, F.E.; Marulanda, D.M.; Olaya, J.J. Production and characterization of niobium carbide coatings produced on tool steels by thermoreactive deposition/diffusion. Ing. Rev. Chil. Ing. 2014, 22, 189-195. [CrossRef]

25. Orjuela, A.; Rincon, R.; Olaya, J.J. Corrosion resistance of niobium carbide coatings produced on AISI 1045 steel via thermo-reactive diffusion deposition. Surf. Coat. Technol. 2014, 259, 667-675. [CrossRef]

26. Amaya, A.A.; Piamba, O.E.; Olaya, J.J. Vanadium carbide coatings produced on gray cast iron using the thermo-reactive deposition/diffusion technique. Ing. Mec. Tecnol. Desarro. 2015, 5, 333-338.

27. ASTM D6751-15c Standard Specification for Biodiesel Fuel Blend Stock (B100) for Middle Distillate Fuels; ASTM International: West Conshohocken, PA, USA, 2004.

28. ASTM A48M Standard Specification for Gray Iron Castings; ASTM International: West Conshohocken, PA, USA, 2004.

29. ASTM G31-72 Standard Practice for Laboratory Immersion Corrosion Testing of Metals; ASTM International: West Conshohocken, PA, USA, 2004.

30. Babolan, R. Corrosion Tests and Standards: Application and Interpretation, 2nd ed.; ASTM International: West Conshohocken, PA, USA, 2005; p. 882.

31. Shan, Z.J.; Pang, Z.G.; Lou, F.Q.; Wei, F.D. Kinetics of $\mathrm{V}(\mathrm{N}, \mathrm{C})$ and $\mathrm{Nb}(\mathrm{N}, \mathrm{C})$ coatings produced by $\mathrm{V}-\mathrm{Nb}-\mathrm{RE}$ deposition technique. Surf. Coat. Technol. 2012, 206, 4322-4327. [CrossRef]

32. Neeft, J.P.A.; Nijhuis, T.X.; Smakman, E.; Makkee, M.; Moulijn, J.A. Kinetics of the oxidation of diesel soot. Fuel 1997, 76, 1129-1136. [CrossRef]

33. Sundus, F.; Fazal, M.A.; Masjuki, H.H. Tribology with biodiesel: A study on enhancing biodiesel stability and its fuel properties. Renew. Sustain. Energy Rev. 2017, 70, 399-412. [CrossRef]

34. Fernandes, F.A.P.; Gallego, J.; Picon, C.A.; Tremiliosi Filho, G.; Casteletti, L.C. Wear and corrosion of niobium carbide coated AISI 52100 bearing steel. Surf. Coat. Technol. 2015, 279, 112-117. [CrossRef]

(C) 2018 by the authors. Licensee MDPI, Basel, Switzerland. This article is an open access article distributed under the terms and conditions of the Creative Commons Attribution (CC BY) license (http://creativecommons.org/licenses/by/4.0/). 